\title{
The effects of topical application of sunflower-seed oil on open wound healing in lambs 1
}

Efeitos da aplicação tópica de óleo de semente de girassol em feridas cutâneas, em carneiros

Silvio Romero Marques ${ }^{2}$, Christina A. Peixoto ${ }^{3}$, Júlio Brando Messias ${ }^{4}$, Alessandra Ribeiro de Albuquerque ${ }^{5}$, Valdemiro Amaro da Silva Junior ${ }^{6}$

1. Department of Animal Morphology and Physiology and Medicine Veterinary, Federal Rural University of Pernambuco. Brazil.

2. Prof. Assistant of Department of Veterinary Medicine, Federal Rural University of Pernambuco. Brazil.

3. Researcher of Department of Pathology and Cellular Biology, Ageu Magalhães Research's Center,

Federal University of Pernambuco. Brazil.

4. Prof. Assistant of Biological Science Center, University of Pernambuco. Brazil.

5. Veterinary autonomous.

6. Associate Prof. of Department of Animal Morphology and Physiology, Federal Rural University of Pernambuco. Brazil.

\section{ABSTRACT}

PURPOSE: To demonstrate the effects of the use of sunflower seed oil on the treatment of skin wounds.

METHODS: Eighteen male Saint Inês lambs were divided in 3 groups according to the pos-operative (7, 14 and 21 days). After antisepsis and local anestesia, two $4 \mathrm{~cm}^{2}$ wounds on each side of the thoracic region, close to the scapule were surgically produced. The experimental wounds were treated with sunflower seed oil, with high concentration of linoleic acid (LA), and the control ones with sterilized Vaseline. Biopsies of the posoperative wounds tissue were performed on the $7^{\text {the }} 14^{\text {th }}, 21^{\text {st }}$ days and histologically evaluated.

RESULTS: Topic application of sunflower seed oil accelerated healing process at the 7th and 21st days, reducing wound area and increasing wound contraction. Granulation tissue increased faster on treated wounds. The epidermis of the treated wounds was completely recovered when compared to control wounds.

CONCLUSION: The topic use of sunflower seed oil accelerated the healing process, and it can be used as an alternative therapy on second intention wound healing.

Key words: Sunflower-seed oil. Topic use. Wound healing.

\section{RESUMO}

OBJETIVO: Demonstrar os efeitos do uso de óleo de semente de girassol no tratamento de feridas cutâneas.

MÉTODOS: Dezoito carneiros da raça Santa Inês foram divididos em 3 grupos de acordo com o pós-cirúrgico (7, 14, e 21 dias). Após antisepsia e anestesia local foram produzidas cirurgicamente duas feridas de $4 \mathrm{~cm}^{2}$ em cada lado da região torácica próxima 
escápula. As feridas experimentais foram tratadas com óleo de semente de girassol, com alta concentração de ácido linoléico (LA) e as controles com vaselina esterilizada. Biopsias dos tecidos das feridas pós-cirúrgicas foram realizadas no $7^{\circ}, 14^{\circ}$ e $21^{\underline{0}}$ dias e avaliadas histologicamente.

RESULTADOS: A aplicação tópica do óleo de semente de girassol acelerou o processo de cicatrização no $7^{\circ}$ e $21^{\circ}$ dias, reduzindo a área e aumentando a contração das feridas. $\mathrm{O}$ tecido de granulação se desenvolveu mais rapidamente em feridas tratadas. A epiderme das feridas tratadas estava completamente reconstituída em relação às feridas controle.

CONCLUSÃO: O uso tópico do óleo de semente de girassol acelerou a cicatrização, podendo ser utilizado como alternativa terapêutica na cicatrização de feridas por segunda intenção.

Descritores: Óleo de semente de girassol. Uso tópico. Cicatrização de feridas.

\section{Introduction}

Damage to the skin frequently provoke wounds or extensive loss of tissues, and to reestablish functional integrity a complex process of wound healing begins. ${ }^{1,2}$ This sequence involves the migration of cells to the wound, proliferation of different cells types, and changes in the synthetic and secretory cellular activities.,

Arachidonic acid is one of the most prominent polyunsaturated fatty acids in the skin, and its functional role depends largely on the generation of biologically potent oxidative metabolites. ${ }^{5}$ Eicosanoids, arachidonic acid derivatives, act as inflammatory mediators. They are chemotactic agents for leukocytes, stimulating vessel dilation and induce platelet aggregation. ${ }^{6}$ The eicosanoid family consists of prostaglandins, thromboxanes, leukotrienes, and other hydroxy fatty acids. ${ }^{7,8}$ These compounds participate in many physiological and pathological processes and are potent regulators of cell function. ${ }^{10,11}$ According to Ziboh et al. ${ }^{5}$ the synthesis of pro-inflammatory mediators generated from arachidonic acid can possibly be modulated by a diet rich in linoleic acid (LA).

Working with cutaneous application of LA in rats, Hartop and Prottey, 12 suggested that this fatty acid enhances the chemotaxis of polymorphonuclear leucocytes after tissue injury. Prottey ${ }^{13}$ also observed a similar cellular migration after intraperitoneal injections of LA. Later, Moch et al. ${ }^{14}$ confirmed that LA is a potent proinflammatory mediator causing intense accumulation of leukocytes and macrophages. Furthermore, LA is an essential substance for regulation of the sequence of biochemical events that precede the fibroblastic cells mitogenesis . ${ }^{15}$

Excellent results have been obtained when the linoleic acid was applied cutaneously on wounds, pressure sores and other skin lesions to accelerate the human healing process ${ }^{16,6}$ Therefore, among other products whose composition has a high concentration of polyunsaturated fatty acids, sunflower-seed oil with its high concentration of $\mathrm{LA}^{16,17,18,19,6}$, could be used as a new alternative for treatment of wounds.

The present work evaluates the clinical and histopathological aspects of cutaneous application of sunflower-seed oil with a high concentration of linoleic acid (65\%) on the healing of surgically created open wounds on lambs.

\section{Methods}


The study protocol and procedures were reviewed and approved by the Committee of Ethics of the Department of Veterinary Medicine, Universidade Federal Rural de Pernambuco, Recife. Eighteen clinically healthy young male Saint Inês lambs weighing 10-15 kg were used in the experiment. Six animals per group were maintained in a box $\left(9 \mathrm{~m}^{2}\right)$ with a concrete floor covered with a $20 \mathrm{~cm}$ layer of sugar cane husks that was changed every 24 hours. Their diet was Pennisetum purpureum grass and balanced commercial food offered three times a day, along with water and mineral salt "ad libitum".

Local subcutaneous anesthesia with Lidoston ${ }^{\circledR}$ (lidocaine 2\%), using the invertedL technique, was administered on all animals. Povidine ${ }^{\circledR}$ (polivinil-pirrolidona-iodine), followed by alcohol at $70 \%$ was used at the operatory field. Two $4 \mathrm{~cm}^{2}$ wounds close to the scapula on each side of the thoracic area were surgically produced in all animals. Animals were divided into groups according to the length of time they were observed postoperatively $(7,14$, and 21 days) to evaluate subjective, planimetric and histopathologic parameters. Experimental wounds on the right side were treated with rayon gauze with sunflower-seed oil (Cocinero, Molinos - Argentina), containing a high concentration (65\%) of linoleic acid (LA). On the left side, the control wounds were treated with sterilized pure petrolatum (Lafere - Recife) on rayon gauze. A bandage was placed around the animal's thoracic perimeter, with the same width as the gauze that covered the wounds. After the surgical procedures, the animals continued their normal diet, and did not receive any antibiotic or anti-inflammatory treatment.

The wounds were rinsed every 24 hours with physiologic saline solution and new rayon gauze containing sunflower-seed oil. Pure petrolatum was placed on the control wounds. This procedure was repeated for 7, 14, 21 days for the first, second and third groups respectively.

Animals were divided into groups according to postoperative observation time (7,14, and 21 days) to evaluate subjective and histopathologic parameters. Subjective observations were also made on postoperative day 3.

The wounds were evaluated according to the existence of edema, hyperemia, exsudato, granulation tissue and crust. Before biopsy, the wounds were measured with pachymeter (Stainless Hardened 708754) and photographed using a digital camera (Sony/Mavica). The wound area was estimated according to Prata et al. ${ }^{20}$, on the $7^{\text {th }}, 14^{\text {th }}$, and $21^{\text {th }}$ day postoperative using the following equation:

\section{$\mathbf{A}=$ ? $\times \mathbf{R} \times \mathbf{r}$}

Where "A" represents the area, " $\mathrm{R}$ " represents larger radius and " $\mathrm{r}$ " the smaller radius of the lesion.

The wounds degree of contraction was calculated by equations proposed by Ramsey et al. ${ }^{21}$ :

\section{Percent of contraction $=100 \times\left(W_{0}-W_{i}\right) / W_{0}$}

Where $\mathrm{W}_{0}=$ original area of the wound; $\mathrm{Wi}=$ area of the wound at the time of the evaluation (7, 14 and 21 days) and expresses in percent. The results were represented as means ? standard deviation and the statistical analysis was performed by test $t$ of StudentNewman-Keuls where $\mathrm{P}<0,05$ were considered significant.

Skin biopsies were taken on the $t^{\text {th }}, 14^{\text {th }}$ and $21^{\text {st }}$ days postoperatively, and in order to take tissue adjacent to the wound, fragments were extended $1 \mathrm{~cm}$ from each margin and deepened to the muscular plane. The fragments were immersed in Bouin's fixative solution. For histological examination, the fixed specimens were processed 
routinely and embedded in paraffin. Sections with 5 ? $\mathrm{m}$ thickness were stained with hematoxylin and eosin. ${ }^{22}$

\section{Results}

Effects of sunflower-seed oil on planimetric parameters of area and contraction

On the $3^{\text {rd }}$ day of the experimental period, the experimental wounds treated with sunflower-seed oil showed a statistically significant reduction $(\mathrm{p}<0,05)$ of the measured area (Table 1) and an increase of contraction (Table 2).

TABLE 1 - Area $\left(\mathrm{cm}^{2}\right)$ of wounds

\begin{tabular}{l|cc}
\hline \hline & \multicolumn{2}{|c}{ Experimental groups } \\
\hline Time (days) & Control & Treated \\
\hline $\mathbf{3}(\mathbf{n}=\mathbf{1 2})$ & $4.19 ? 0.53$ & $3.61 ? 0.75^{*}$ \\
$\mathbf{7}(\mathbf{n = 1 8})$ & $2.98 ? 0.59$ & $2.40 ? 0.58^{*}$ \\
$\mathbf{1 4}(\mathbf{n = 1 2})$ & $0.74 ? 0.44$ & $0.53 ? 0.29$ \\
$\mathbf{2 1}(\mathbf{n = 6})$ & $0.28 ? 0.14$ & $0.09 ? 0.04^{*}$ \\
\hline \hline
\end{tabular}

*Statistically significant $(\mathrm{p}<0.05)$.

TABLE 2 - Percent contraction of wounds

\begin{tabular}{l|cc}
\hline \hline & \multicolumn{2}{|c}{ Experimental groups } \\
\hline Time (days) & Control & Treated \\
\hline $\mathbf{3}(\mathbf{n}=\mathbf{1 2})$ & $-4.85 ? 13.15$ & $9.76 ? 8.76^{*}$ \\
$\mathbf{7}(\mathbf{n}=\mathbf{1 8})$ & $25.45 ? 14.69$ & $40.10+14.54^{*}$ \\
$\mathbf{1 4}(\mathbf{n = 1 2})$ & $81.49 ? 11.03$ & $86.73 ? 7.26$ \\
$\mathbf{2 1}(\mathbf{n = 6})$ & $93.02 ? 3.54$ & $97.74 ? 1.04^{*}$ \\
\hline \hline
\end{tabular}

*Statistically significant $(\mathrm{p}<0.05)$.

In contrast, control wounds exhibited increased areas (Tables 1, 2) and had no wound contraction (Figures 1, 2).

On the $7^{\text {th }}$ day, treated wounds presented borders with initial irregularity, and the wounds also showed a reduction of area and an increase of wound contraction that were confirmed statistically $(\mathrm{p}<0.05)$ (Tables 1,2$)$.

On one hand, statistical difference was not observed in relation to the area and contraction parameters between treated and controls (Tables 1,2). On the other hand, very good clinical progress of treated wounds in second week was observed $\left(14^{\text {th }}\right.$ day).

On the $21^{\text {st }}$ day, treated wounds presented a reduction statistically significant $(\mathrm{p}<0,05)$ in the wound area and in the increase of wound contraction $\left(0,09 \mathrm{~cm}^{2} ? 0,04\right.$ $\mathrm{cm}^{2} ; 97,7 \% ? 1,04 \%$ ) at the end of the healing process of the experiment (Tables 1, 2). It's important to point out that some animals showed a contraction of $99 \%$ of the total area of the wound. Control wounds were in the final stage of the healing process (Table 
1,2) and exhibited small central areas of granulation tissue. However, these control wounds still needed some more time to complete healing.

\section{Clinical evaluation}

After skin excisions on day, it was possible to observe control wounds with hyperemia, necroses and highly vascularized granulation tissue (Figure 1A). Although the wound borders were geometrically well defined, edema and crust surrounding the wound margins were generally observed. In this experimental stage, the most striking feature of the treated wounds was a well-preserved vascular bed with discreet hyperemia and also the presence of edema in granulation tissue (Figure 1B). Although the treated wounds presented well-preserved borders, they had a mild alteration in the original geometric pattern, characterizing the initial contraction of wound margins.

After skin excision on the $3^{\text {rd }}$ day, the control wounds presented well-defined borders, preserved geometric shape and a little crust area on the inferior margin (Figure 1C). Furthermore, an absence of shrinkage promoting a diameter increase was detected (Table 3)

TABLE 3 - Diameter $(\mathrm{cm})$ of wounds

\begin{tabular}{l|cc}
\hline \hline & \multicolumn{2}{|c}{ Experimental groups } \\
\hline Time (days) & Control & Treated \\
\hline $\mathbf{3}(\mathbf{n = 1 2})$ & $2.32 ? 0.13$ & $2.15 ? 0.22^{*}$ \\
$\mathbf{7}(\mathbf{n = 1 8})$ & $1.96 ? 0.19$ & $1.75 ? 0.19^{*}$ \\
$\mathbf{1 4}(\mathbf{n = 1 2})$ & $0.93 ? 0.28$ & $0.80 ? 0.21$ \\
$\mathbf{2 1}(\mathbf{n = 6})$ & $0.58 ? 0.15$ & $0.33 ? 0.07^{*}$ \\
\hline \hline
\end{tabular}

*Statistically significant $(\mathrm{p}<0.05)$.

In contrast, treated wounds revealed the presence of hyperemic areas and absence of edema, due to the clear definition of wound borders (Figure 1D). In addition, the following aspects of the treated wounds were observed: no secretion on the wound bed, evident granulation tissue in its superior area, and an early shrinkage (Figure 1D).
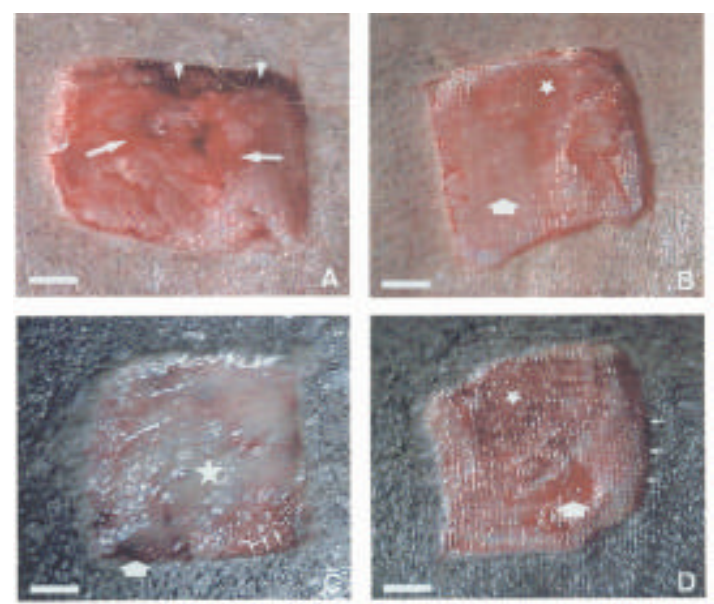

FIGURE1 - A-D. Subjective aspects of control wounds and wounds treated with sunflower-seed oil on $1^{\text {st }}$ and $3^{\text {rd }}$ day. A-C. Control wound. A, note hyperemic (arrows) and necrosis areas (arrowheads) in control wound after 24 hours. C, on control wounds on the $3^{\text {rd }}$ day we observed vaseline adhered to the bed wound 
(star), and crust area on the wound edge (large arrow). A hyperemic area was also observed in the bed wound (small arrows), Bar, $0.5 \mathrm{~cm}$. B-D. Treated wounds. B, hyperemic areas on the wound bed (star), and well-preserved vascular bed (large arrow) were observed in treated wounds after 24 hours. D, absence of edema in the edge areas (small arrows), and granulation tissue (star) in $3^{\text {td }}$ day treated wounds. Observe also a small hyperemic area (large arrow), Bar, $0.5 \mathrm{~cm}$.

On the $7^{\text {th }}$ day, a high quantity of crust was detected surrounding the control wounds' margins, which showed granulation tissue in the central area, hyperemia and edema (Figure 2A). At the same time, treated wounds not only had no crust, but also presented well-developed granulation tissue. In addition, no secretion in the treated wound bed was observed, although the presence of a mild hyperemia and few edema areas were detected (Figure 2B). Treated wounds had a geometrical alteration characterized by approximation of borders. This process was strengthened by significant reduction in the area and increase of the contraction (Tables 1, 2; Figure 2B).

On the $14^{\text {th }}$ day, treated wounds were observed: no secretion, edema or hyperemia on the wound bed. Although the treated wounds presented better clinical evolution than the control wounds, no statistically significant difference was observed for area and shrinkage of wound parameters (Tables 1, 2; Figures 2C, 2D).

Twenty-one days after surgical excision, control wounds had small areas of central granulation tissue, though they needed more time for total healing resolution (Tables 2, 3; Figures 2E, 2F). Treated wounds showed complete epithelial resurfacing with hair follicles lining the borders of wounds characterizing a centripetal evolution of contraction. Some animals presented $99 \%$ wound contraction.
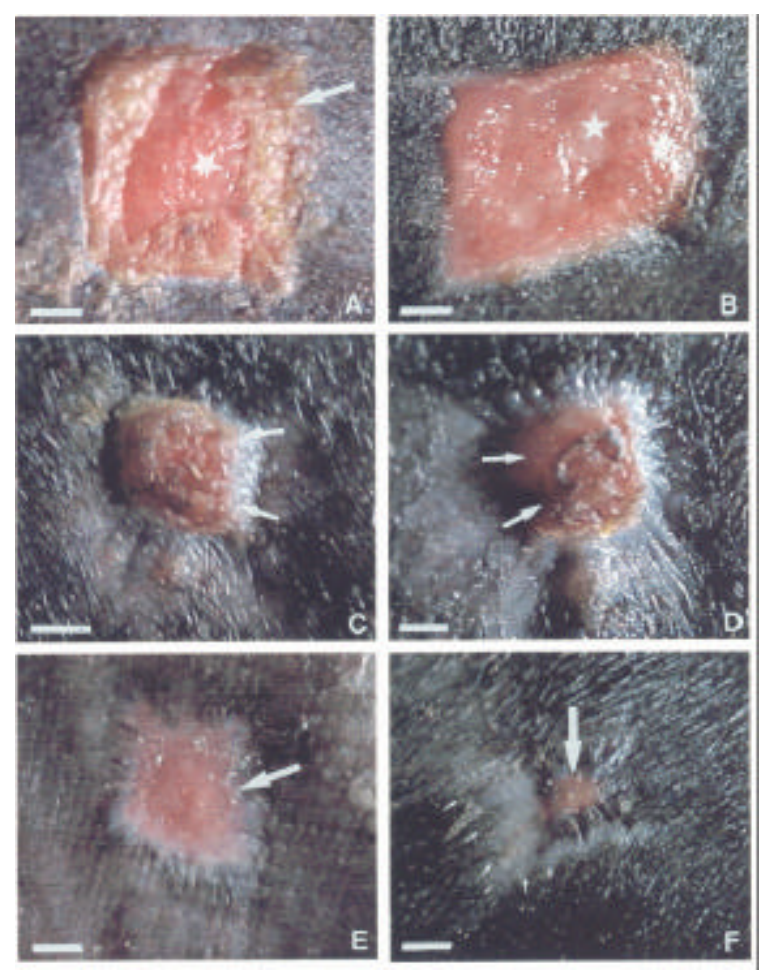

FIGURE 2 - A-F. Subjective observations of control and treated wounds at 7, ${ }^{14}$ and 21 days. A, C and E. Control wounds - A, crust area (arrow) and granulation tissue (star) in control wound on the $7^{\text {th }}$ day. C, note the distinct line between granulation tissue and the epithelializated region in the edge of control wound on the $14^{\text {th }}$ day (arrows). E, granulation tissue in the central area surrounded by epithelialization area (arrow) in control wound on the $21^{\text {th }}$ day, Bar, $0.5 \mathrm{~cm}$. B, D and F. Treated wounds - B, absence of crust and well developed granulation tissue (star) were observed in treated wound on the $7^{\text {th }}$ day. D, the granulation tissue (arrows) and large epithelializated region in the wound edge in treated wound on the $14^{\text {th }}$ day. F, note the 
reduced area in the bed wound (arrow), and also a large epithelialization region in treated wound edge on the 21st day (small arrows), Bar, $0.5 \mathrm{~cm}$.

\section{Histological evaluation}

On the $7^{\text {th }}$ day after excision, the control wounds had a great presence of crust, highly infiltrated granulation tissue with inflammatory cells, and many active spindleshaped cells, which were fibroblasts (Figures 3A, 3C). These features indicated an initial organization of the granulation tissue. In treated wounds no crust was observed between the transitional area of hyperplastic epithelium and healing tissue. Granulation tissue was also more developed with minor inflammatory infiltration, the presence of plasma cells, active fibroblasts around new formed capillaries, and abundant extracellular matrix (Figures 3B, 3D).
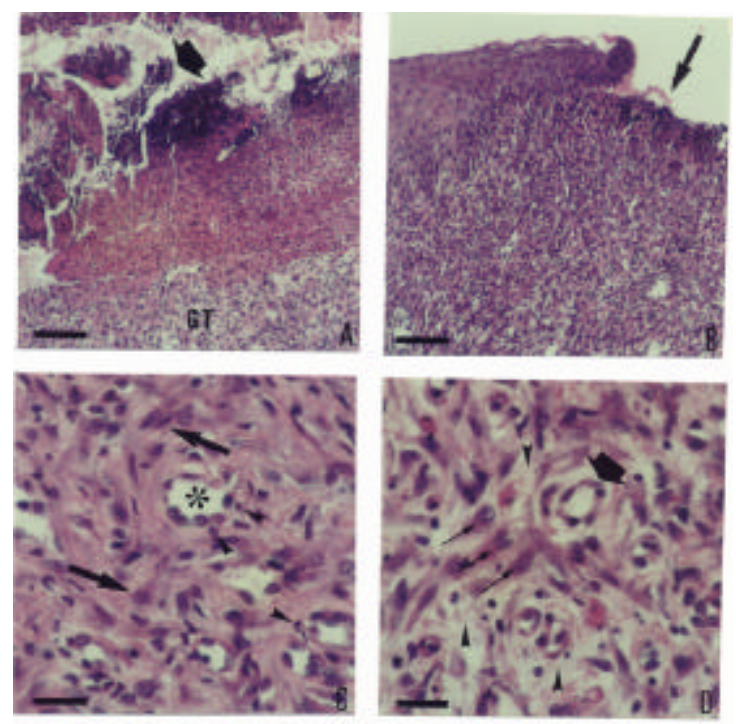

FIGURE 3 - Histopathologic observations of control and treated wounds at 7 days. A-C. Control wound. A, observe extensive area of crust (large arrow) over the granulation tissue (GT), Bar, 250? m. C, granulation tissue presenting several active fibroblasts (arrow) and inflammatory cells (arrowheads) surrounding capillaries (asterisk), Bar, 25? m. B-D. Treated wound. B, note the hyperplasic epithelium (E) near the transitional region of the wound bed. No crust was observed (arrow), Bar, 250? m. D, granulation tissue exhibiting intense production of extracellular matrix (arrowheads). Active fibroblasts (thin arrows) and a capillary with a reduced diameter (large arrows) are also indicated, Bar, $25 ? \mathrm{~m}$.

On the $14^{\text {th }}$ day after excision, treated wounds presented a strong epidermic hyperplasia, though, no epidermic crests moving towards the subjacent connective tissue were detected (Figures 4A, 4B). Furthermore, fibroblasts exhibited a high activity of synthesis and a mild inflammatory infiltration in the subepidermic tissue next to the transitional area between the skin and cicatricial tissue (Figure 4B). In the cicatricial area, wounds treated with sunflower-seed oil had a slight superficial crust and the granulation tissue was more evolved than that observed in control wounds (Figure 4C).

In treated wounds the epithelium still presented a hyperplastic appearance, and fibroblasts with characteristic arrangement of miofibroblasts were observed (Figure 4D). Also, the treated wounds presented a reduction of inflammatory cells in ground substance and in the newly formed vascular bed (Figures 4E, 4F). 

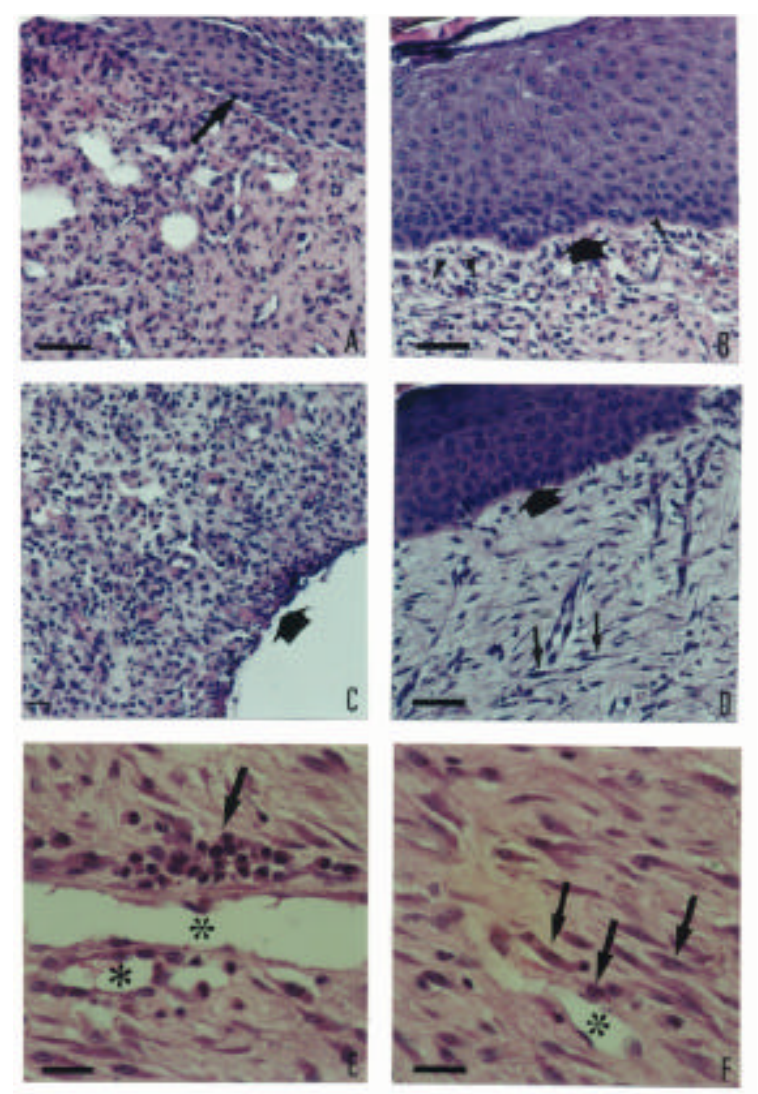

FIGURE 4 - Histopathological aspects of control wounds and wounds treated with sunflower-seed oil on $14^{\text {th }}$ day (Hematoxylin-Eosin). A, E. Control wounds. A, healing transitional area showing epidermal crest of hyperplasic epithelium migrating to the connective tissue (arrow), Bar, 100? m. E, Deep areas of granulation tissue with capillaries (asterisk) surrounded by plasma cells (arrow), Bar, 25? m. B, C, D and F. Treated wounds. B, hyperplasic epithelium showing intense inflammatory infiltration (arrowheads), Bar, 100 ? $\mathrm{m}$. Note the absence of epidermal crests (large arrow). C, transitional healing area without crust (large arrow) Bar, $100 ? \mathrm{~m}$. D, connective tissue presenting miofibroblastic cells organized in the traction area (arrows), under the hyperplasic epithelium (large arrow), Bar, 100? m. F, Deep areas of granulation tissue with capillary (asterisk) surrounded by fibroblasts (arrows), Bar, 25? m.

Wounds treated with sunflower-seed oil had a better clinical and microscopic healing process, than those of control wounds at 14 days, though no statistical significance related to the area of reduction and contraction could be observed.

On the $21^{\text {st }}$ day after surgical excision, the control wounds showed a mild process of epithelialization beneath an area of crust, and highly infiltrated connective tissue with polymorphonuclear leukocytes (Figures 5C, 5E). This process needed more time to conclude epithelial resurfacing due to the evident area of epithelium discontinuity (Figure 5A). Wounds treated with sunflower-seed oil with a high concentration of linoleic acid showed total epithelial resurfacing and subjacent connective tissue very active fibroblastic cells in the synthesis of extracellular matrix, especially collagen fibers (Figures 5B, 5D). In addition, the amorphous ground substance had a mild quantity of inflammatory cells (Figure 5F). 


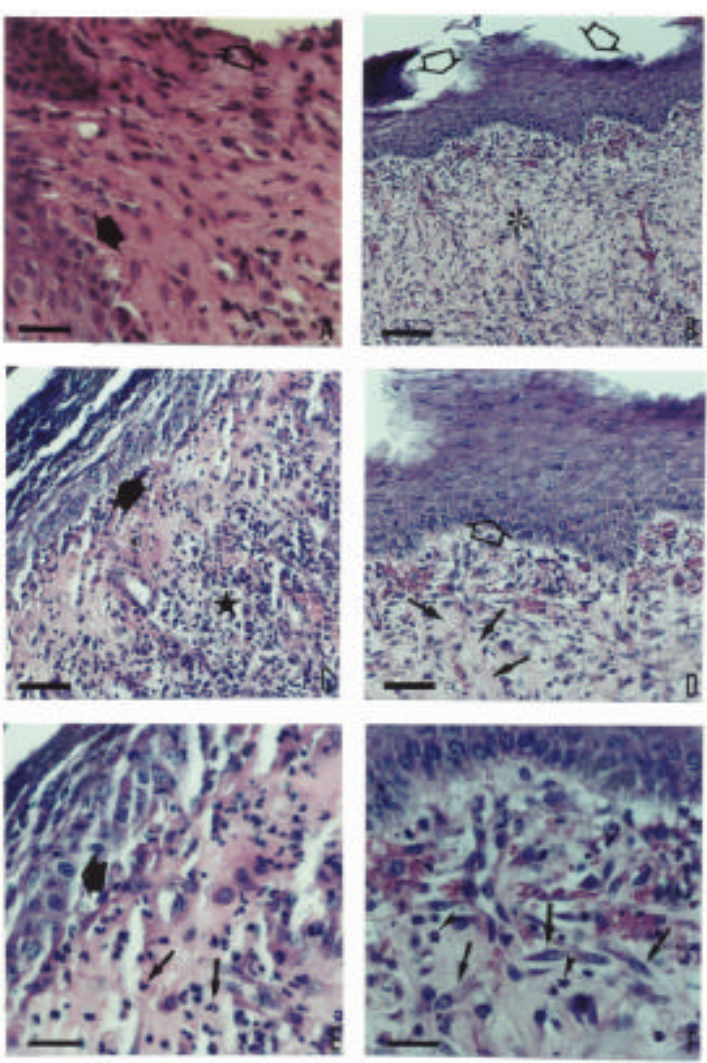

FIGURE 5 - Histopathological aspects of control wounds and wounds treated with sunflower-seed oil on $21^{\text {st }}$ day (Hematoxylin-Eosin). A, C and E. Control wounds - A, healing transitional area showing evident discontinuity of epithelium (open arrow) and epidermal crest (large arrow), Bar, 25? m. C, Epithelial proliferation in subjacent area of crust (large arrow), and connective tissue with inflammatory infiltration (star), Bar, $100 ? \mathrm{~m}$. E, detail of the last micrograph showing epithelium (large arrow) and polimorphonuclear cells (arrow), Bar, 25? m. B, D and F. Treated wounds - B, epithelialization region (open arrows), and subjacent connective tissue in remodeling process (asterisk), Bar, 100? m. D, Detail of hyperplasic epithelium without crests (open arrow), and ground substance of connective tissue (arrows), Bar, 100 ? m. F, Detail of connective tissue showing active fibroblasts (arrows) and few polimorphonuclear cells (arrowheads), Bar, 25? m.

\section{Discussion}

Essential fatty acids' (EFA) effectiveness on problems related to skin lesions has been studied since 1929, when the first observations of skin lesions provoked by a shortage of EFA levels in foods were made. ${ }^{23,24}$ Linn and Shepherd ${ }^{25}$ described the cure of those alterations by topical application of EFAs. Essential fatty acids, linolenic acid and arachidonic acid are polyunsaturated vegetable lipids that cannot be synthesized by the animal organisms, necessitating renewal by diet. ${ }^{26}$

In 1954, Sinclair and Basnayeke ${ }^{27}$ described a dry skin desquamation or dermatosis provoked by the rate of transepidermal water loss related to a dietary deficiency in essential fatty acids. Later, Van Dorp ${ }^{28}$ and Prottey et al. ${ }^{29}$ observed a reversion and cure of both scaly lesions and dermatosis after topical application of sunflower-seed oil with a high concentration of linoleic acid. Hartop and Prottey ${ }^{30}$ had showed that when applied cutaneously, both linoleic and ?-linoleic acids, but neither dihomo-?-linoleic nor arachidonic acid, restored the epidermal permeability to normal rates in rat skin. According to Prottey ${ }^{13}$ linoleic and arachidonic acids are important in 
the maintenance of a cutaneous barrier to water loss and as precursor of prostaglandins, which are thought to be involved in both the regulation of cell division and differentiation of epidermis, and consequently in the control of skin scaliness. Elias and Brown ${ }^{10}$ showed that EFAs are precursors of pharmacologically active substances such as thromboxanes, prostaciclins, prostaglandins and others that are involved in cellular division regulation and epidermic differentiation.

Linoleic acid is a powerful pro-inflammatory mediator that causes a migration of granulocytes and macrophages as well as important changes in granulation tissue. ${ }^{14}$ According to Glasgow and Eling ${ }^{15}$ linoleic acid is essential for regulation of the biochemical events that precede the fibroblastic mitogenesis since it stimulates some factors of cellular growth.

In open wounds, epithelialization occurs after the development of a granulation bed ${ }^{31}$, which is also formed when the repair process of connective tissue is necessary. ${ }^{1}$ By definition, this is an inflammatory growth of connective tissue characterized by synthesis and deposition of products of fibrogenic cells that can be divided in three phases: (a) cell mobilization and proliferation; and (b) synthesis and deposition of collagen products, glycosaminoglycans and extracellular matrix, and (c) a final organization or remodeling of the wound scar. ${ }^{32,4}$

This paper evaluated the evolution of the wound healing process in young male lambs utilizing cutaneous application of sunflower-seed oil with a high concentration of linoleic acid, describing a simple methodology for wound management and the progression of wound healing.

After $3^{\text {rd }}$ day of sunflower-seed oil treatment, we observed acceleration in the evolution of the cicatricial process of the treated wounds by reductions of wound area, as an increase of $300 \%$ in wound contraction. These results confirm those obtained by Baie and Sheikh ${ }^{33}$, which demonstrated the efficiency of amino acids and essential fatty acids in wound healing. Although a histopathological evaluation of the wounds has not been made, morphometrical findings pointed out acceleration in the sequential biological events with a mild growth of granulation tissue and absence of edema and secretion. Macroscopical findings of the healing process on the $3^{\text {rd }}$ day, can be related to the migration, proliferation and cellular differentiation, as well as to the pathognomonics of the inflammatory phase for repairing tissue. ${ }^{19}$

By the seventh day after excision, the wounds treated were more evolved macroscopically than the control wounds due to a great development of granulation tissue, contraction in the outer edge of borders and absence of secretion. On the other hand, the control wounds had extensive areas of crust, hyperemia and edema. In that same period, treated wounds had a reduction of $10 \%$ and $20 \%$ in the diameter and area, respectively, as well as an increase of $37 \%$ in contraction in relation to the control wounds. Histopathological data in treated wounds on the seventh day indicated a more advanced repair process than control wounds, due to fewer inflammatory infiltration and presence of active fibroblasts around newly formed vessels.

The acceleration of the inflammatory process can be explained by biological and biochemical features of the linoleic acid. This polyunsaturated fatty acid (18:2n-6) is changed by desaturation and elongation of its molecule to arachidonic acid (20:4n-6) which is metabolized via the 5-lipoxygenase and clyclooxygense pathway in leukotrienes ( $\mathrm{LTB}_{4}, \mathrm{LTC}_{4}$ and LTD4), prostaglandins $\left(\mathrm{PGE}_{2}, \mathrm{PGF}_{2}, \mathrm{PGD}_{2}\right.$ and $\left.\mathrm{PGI}_{2}\right)$ and thromboxane $\mathrm{A}_{2}$ by polymorphonuclear cells. These substances produced by LA have proinflammatory properties that can stimulate new vascularization locally, cell migration, 
$\underset{34,19}{\text { proliferation and fibroblastic differentiation as well as extracellular matrix synthesis., }}$,

While evaluating wounds on the fourteenth day of treatment, we detected no morphometrical differences between the two groups. However clinical data showed a more advanced cicatricial stage in treated wounds. These results are in accordance with findings of Baie and Sheikh ${ }^{33}$ who had treated rats with fish oil, and by the end of twelve days had obtained $80 \%$ of wound contraction, though our data pointed out $87 \%$ contraction in the same period.

In the wound contraction area, miofibroblastic cells had an important role in centripetal closeness and approximation of wounds borders. ${ }^{1}$ In lambs, our results showed that wounds treated with sunflower-seed oil had well arranged miofibroblastic cells in the contraction area while in the control wounds these cellular types were in high synthesis activity of matrix components showing little organization in wound borders.

Ono et al. ${ }^{35}$ indicated the importance of cytokines and growth factors in the wound healing process. Many of these factors, such as the epidermal growth factor (EGF), fibroblastic basic growth factor (bFGF); platelet-derived growth factor (PDGF), transforming growth factor alpha (TGF-?) and interleukin-6 (IL-6) are cytokines that stimulate keratinocyte proliferation. The topical use of bFGF, PDGF e TGF-? in wounds not only facilitates the migration of monocytes, neutrophils, macrophages and fibroblasts, but also stimulates the proliferation of the granulation tissue. ${ }^{35}$ Thus, linoleic acid metabolism seems to play an important function in the EGF-regulated sequence of biochemical events leading to fibroblast mitogenesis, and consequently inducing an early formation of granulation tissue. ${ }^{15}$

By the end of the experimental period (21 days), wounds treated with sunflowerseed oil had approximately $68 \%$ area reduction, and $98 \%$ in wound contraction, although in some animals $99 \%$ wound shrinkage was observed. Hence, our data indicate that the topical use of sunflower-seed oil with high concentration of linoleic acid can be used as an efficient therapy for wound healing, confirming previous work on maturation and remodeling of wounds. 1

The regression of the hyperplasic epidermis observed in this phase can be justified by linoleic acid's anti-inflammatory action as indicated by Ziboh ${ }^{5}$ and Ziboh et al. ${ }^{34}$ In this alternative pathway, the 15-lipoxygenase changes the linoleic acid in 13hydroxyoctadecadienoic acid (13-HODE) that is catalyzed in the epidermis to 13-HODEdiacylglycerol. The epidermal concentration of 13-HODE-substituted diacylglycerol plays a role in vivo in modulating cutaneous hyperproliferation via down-regulation of protein kinase C-? (PKC-?) and reversing the epidermical proliferation by basal levels. ${ }^{35}$ According to Declair ${ }^{4}$, the transforming growth factor (TGF) could be also involved in the anti-inflamatory process since it acts as an inhibitor of cell proliferation in lymphocytes and in most epithelial cells.

At the end of the experiment, on the $21^{\text {st }}$ day, a small quantity of vessels was observed in treated wounds, which could be attributed to a progressive endothelial reduction of the newly formed vessels, described by CORSI et al. ${ }^{1}$ as an event related to the end of the healing process.

Mat Jais et al ${ }^{17}$, Fredalina et al. ${ }^{18}$, and Baie and Sheikh ${ }^{19}$ described the effects of polyunsaturated fatty acids in the wound healing process. These authors demonstrated that wounds in rats when treated with fish oil containing a high concentration of polyunsaturated fatty acid improved dermal wound healing. Moch et al. ${ }^{14}$ observed an efficient topical action of linoleic acid on abdominal lesions produced experimentally in 
rats. Histological analysis of the treated tissue showed that the fish oil acted as a local immunogen causing the migration of both polymorphonuclear leucocytes and macrophages, and resulting in proliferative activity during the appearance of granulation tissue. ${ }^{4}$ Declair ${ }^{36,19}$ observed that topical application of vegetable oil with a high concentration of linoleic acid in hospitalized humans considerably reduced pressure skin sores and accelerated wound healing.

The present work showed by morphometrical, clinical and histological assays that sunflower-seed oil improved the granulation tissue formation and epithelial resurfacing of wounds. Therefore, sunflower-seed oil or other vegetable oils containing a high concentration of linoleic acid, can be indicated as a therapeutic alternative for wound healing process by second intention in veterinary medicine.

\section{References}

1. Corsi RCC, Corsi PR, Pirana S, Muraco FAE, Jorge D Cicatrização de feridas: revisão de literatura. Rev Bras Cir 1994; 84: 17-24.

2. Corsi RCC, Corsi PR, Pirana S, Muraco FAE, Jorge D Fatores que prejudicam a cicatrização das feridas: revisão de literatura. Rev Bras Cir 1995; 85: 47-53.

3. Raghow R. The role of extracelular matrix in post-inflamatory wound healing and fibrosis. FASEB J 1994; 8: 823-31.

4. Declair V. The importance of growth factors in wound healing. Ostomy/Wound Management. 1999; 45: 64-72.

5. Ziboh VA. The significance of polyunsaturated fatty acids in cutaneous biology. Lipids 1996; 31: s249-s53.

6. Declair V. Tratamento de úlceras crônicas de difícil cicatrização com ácido linoléico. Supl Vasc News; 2001; 10: 12.

7. Ribeiro L. Ácidos eicosapentaenóico e docosapentaenóico (omega-3) e prostaglandinas. Recentes Evidências sobre os seus efeitos cardiovasculares: é possível previnir? Sinp Int Ateroscleros. 1989; 5: 12-9.

8. Batlouni M. Agregação plaquetária e insuficiência coronária. É possível prevenir? Sinp Int Ateroscleros. 1989; 5: 26-32.

9. Carlier H, Bernard A, Caselli C. Digestion and absorption of polyunsaturated fatty acids. Reprod. Nutr. Dev. 1991; 31: 475-500.

10. Elias PM, Browm BA. The mammalian cutaneous permeability barrier. Lab Invest 1978; 39: 574-83.

11. Sardesai VM. Nutritional role of polyunsaturated fatty acids. J Nutr Biochem 1992; 3: 154-62.

12. Hartop PJ, Prottey C. Changes in transepidermal water loss and the composition of the epidermal lecithin after applications of pure fatty acid triglycerides to the skin of essential fatty acid - deficient rats. Br J Dermatol 1976a; 95: 255-64.

13. Prottey $\mathrm{C}$. Investigation of Functions of essential fatty acids in the skin. $\mathrm{Br} \mathrm{J}$ Dermatol 1977; 97: 29-47.

14. Moch D, Schewe T, Kuhn H, Schmidt D, Buntrock P. The linoleic acid metabolite 9Ds - hydroxy - 10,12 (E, Z) - octadecadienoic acid is a strong proinflammatory mediator in an experimental wound healing model of the nature biomedical. Biochem Acta. 1990; 49: 201-07.

15. Glasgow WC, Eling GT. Epidermal growth factor simulates linoleic acid metabolic in BAB/C 3T3 fibroblasts. Mol Pharmacol 1990; 38: 503-10. 
16. Declair V. Efeitos do triglicéris de cadeia média na aceleração do processo de cicatrização de feridas. Rev. Nutr Ent Esport 1994; 5: 4-8.

17. Mat Jais AM, Matori MF, Kittakoop P, Sowanborirux K. Fatty acids compositions in Mucus and Roe of Haruan, Channa Striatus, for wound healing. Gen Pharmacol 1998; 30:561-3.

18. Fredalina BD, Ridzwan BH, Zainal AA, Kaswandi M A, Zaiton H, Zali I, Kittakoop P, Mat Jais A M. Fatty acids compositions in local sea cucumber, Stichopus chloronotus, for wound healing. Gen Pharmacol 1999; 33: 337-40.

19. Baie SH, Sheikh KA. The wound healing properties of Channa striatus-cetrimide cream-wound contraction and glycosaminoglycan measurement. J Ethno-Phamacol 2000a; 73:15-30.

20. Prata M, Haddad C, Goldenberg S. Uso tópico do açúcar em ferida cutânea: estudo experimental em ratos. Acta Cir Bras. 1988; 3: 43-8.

21. Ramsey DT, Pope ER, Wagner-Mann C, Berg J N, Swain S F. Effects of tree occlusive dressing materials on healing of full-thickness skin wounds in dogs. Am $\mathbf{J}$ Vet Res 1995; 56: 941-9.

22. Harris HF. On the rapid conversion of haematoxylin into haematein in staining reactions. J Appl Microsc Lab Methods. 1900; 3: 777.

23. Burn GO, Burn MM. A new deficiency disease produced by the rigid exclusion of fat from diet. J Biol Chemis 1929; 82: 435-67.

24. Burn GO, Burn MM. The nature of fatty acids essential in nutrition. J Biol Chemis 1930; 86:587-621.

25. Linn DS, Sherphed MI. Evolution of vitamin F. Drug Cosm Indus 1936; 38: 329.

26. Laguna J. Química de los lípidos. In: Laguna J. Bioquímica. México: La Prensa Medica Mexicana; 1960. p.205-28.

27. Sinclair HM; Basnayeke V. Skin permeability in deficiency of essential fatty acids. J Physiol 1954; 126: 55.

28. Van Torp DA. Essential fatty acids and prostaglandins. XXIV Inter Cong Pure Appl Chem . London, Butterworth. 1974; 2: 117.

29. Prottey C, Hartop PJ, Press M. Correction of cutaneous manifestations of essentials fatty acids deficiency in man by application of sunflower seed oil to the skin. J Invest Dermatol 1975; 64: 228.

30. Hartop PJ, Prottey C, Black J G, McCormack J I. The repair of impaired epidermal barrier function in rats by the cutaneous application of linoleic acid. Br J Dermatol . 1976b; 94: 13-21.

31. Fitch RB, Swaim SE. The role of epithelialization in wound healing. Small Animal Wound Healing. 1995; 17: 167-77.

32. Chvapil M, Pfister T, Escalada S, Ludwig J, Peacock Jr E E. Dynamics of healing of skin wounds in as compared with rats. Exp Mol Pathol . 1979; 30: 349-59.

33. Declair V, Carmona MP, Cruz JA. Ácidos graxos essenciais (AGEs) protetores celulares dos mecanismos agressivos da lesão hipóxica. Rev Derm Atual. 1998; 4: $15-7$.

34. Baie SH, Sheikh KA. The wound healing properties of Channa striatus-cetrimide cream - tensile strength measurement. J Ethno-Phamacol 2000b; 71: 93-100.

35. Ziboh VA, Miller CC, Cho Y. Metabolism of polyunsaturated fatty acids by skin epidermal enzymes: generation of antiinflamatory and antiproliferative metabolites. Am J Clin Nutr 2000; 71: 361S-6S.

36. Ono I, Zhou LJ, Tateshita T. Effects of a collagen matrix containing prostaglandin $\mathrm{E}_{1}$ on wound contraction. J Dermatol Sci 2001; 25: 106-15. 
37. Declair V. Aplicação de triglicéris de cadeia média (TCM) na prevenção de úlceras decúbito. Rev Enferm 1993; 84: 27-30.

Correspondence:

Prof. Valdemiro Amaro da Silva Junior

Departamento de Morfologia e Fisiologia Animal da Universidade Federal Rural de Pernambuco

Av. D. Manoel de Medeiros, s/n.

Recife - PE

Tel: (81) 3302-1389

valdemiro.amaro@bol.com.br

Data do recebimento: $28 / 02 / 2004$

Data da revisão: 16/03/2004

Data da aprovação: 02/04/2004

Conflict of interest: none

Financial source: none

\section{How to cite this article:}

Marques SR, Peixoto CA, Messias JB, Albuquerque AR, Silva Jr VA. The effects of topical application of sunflower-seed oil on open wound healing in lambs. Acta Cir Bras [serial online] 2004 May-Jun;19(3). Available from URL: http://www.scielo.br/acb [also in CD-ROM]. 